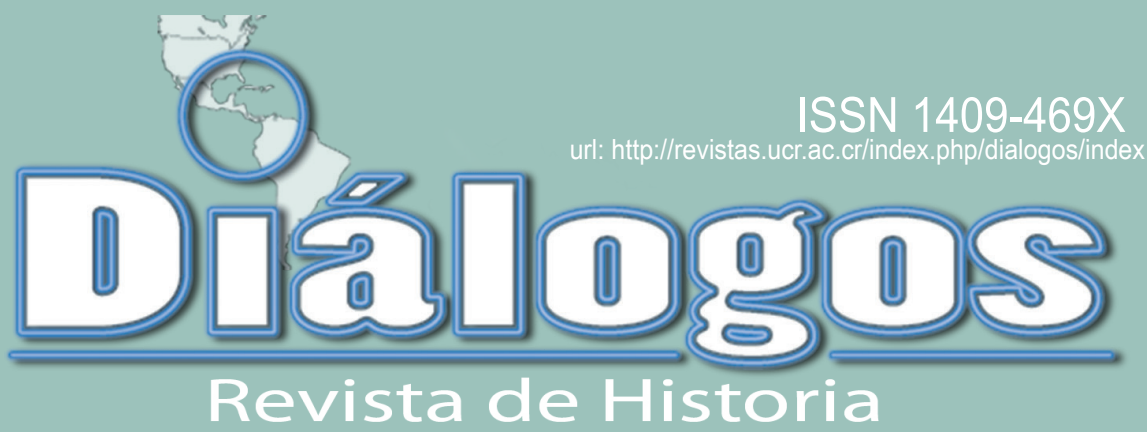

Escuela de Historia. Universidad de Costa Rica Vol. 15 No. 2 Setiembre 2014 - Enero 2015

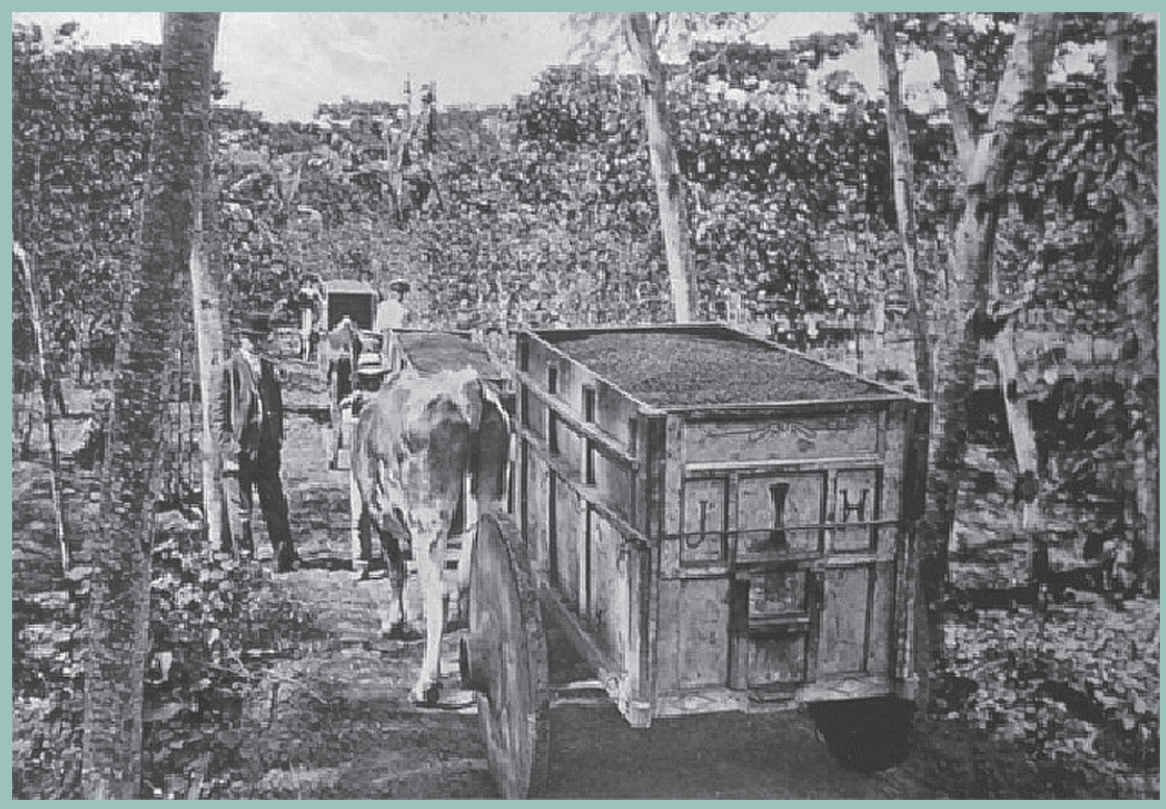

Director de la Revista: Dr. Juan José Marín Hernández juan.marinhernandez@ucr.ac.cr

Editor académico: Dr. David Díaz Arias - david.diaz@ucr.ac.cr Editor técnico: M.Sc. Marcela Quirós G. - marcela.quiros@ucr.ac.cr

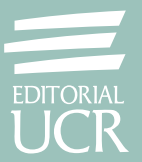




\title{
O FIO DA MEMÓRIA: AS PAISAGENS DO BRASIL HOLANDÊS ${ }^{1 *}$
}

\section{LAS HUELLAS DE LA MEMORIA: LOS PAISAJES DEL BRASIL HOLANDÉS}

\author{
Francisco Isaac D. de Oliveira
}

\begin{abstract}
Palavras-chave
Paisagem, arte, Frans Post, pintura etnográfica, século XVII, Brasil holandês.
\end{abstract}

Palabras clave

Paisaje, arte, Frans Post, pintura etnográfica, siglo XVII, Brasil holandés.

Fecha de recepción: 8 de enero, 2014 - Fecha de aceptación: 9 de julio 2014

\begin{abstract}
Resumo
O objetivo deste texto é estudar a constituição do olhar holandês a partir da visualização da paisagem colonial nas telas dos pintores Frans Post e Albert Eckhout. Um dos temas escolhidos para este trabalho foi o estudo do conceito de memória por meio das imagens do Brasil holandês, sabe-se que os artistas envolvidos no projeto colonial neerlandês buscaram entender este "mundo" pelos conceitos naturais e humanos representados nas pinturas destes. Eles foram os primeiros pintores a retratarem as paisagens americanas com sua gente. Para compreender tal visão é de suma importância estudar as imagens imaginárias que foram erigidas por Post e Eckhout. Vamos utilizar primordialmente como fonte (visual) de pesquisa duas telas: O carro de bois de 1638 e Mameluca de 1643, todas as imagens foram produzidas quando Frans Post e Albert Eckhout estiveram na América holandesa integrando a comitiva do governador João Maurício de Nassau. Buscaremos trabalhar com uma metodologia que privilegie a leitura de fontes primárias visuais para assim compreendermos a paisagem colonial.
\end{abstract}

\section{Resumen}

El objetivo de este trabajo es estudiar la constitución del paisaje colonial holandesa a través de producción visual Frans Post y Albert Eckhout. Uno de los temas escogidos para este trabajo fue estudiar el concepto de memoria a través de imágenes de Brasil holandés, se sabe que los artistas que participan en el proyecto colonial holandesa intentaron entender este "mundo" por los conceptos naturales y humanos representados en estas pinturas. Ellos fueron los primeros pintores para representar paisajes americanos con su gente. Para entender este punto de vista es muy importante estudiar las imágenes imaginarias que se levantaron por Post y Eckhout. Vamos a utilizar principalmente como la investigación (visual) dos pantallas: O carro de bois 1638 y Mameluca de 1643, todas las imágenes fueron producidas cuando Frans Post y Albert Eckhout formaron el séquito del gobernador Johan Maurits de Nassau. Vamos a tratar de trabajar con una metodología que privilegia la lectura de fuentes primarias con el fin de entender el paisaje colonial visual. 


\section{INTRODUÇÃO}

"Neste 1945 o holandês não é para mim um assunto mas uma presença. Conquistou e dirigiu a região brasileira em que nasci e vivo, a mais amada e conhecida. Não o encontro apenas nos livros, mapas, nótulas e relatórios da Geoctroyer Westindische Companie mas na recordação inconsciente de sua visita de vinte e quatro anos, inapagável na memória nordestina." (CASCUDO. 1956.p.13).

Luís da Câmara Cascudo autodefinia-se como "provinciano incurável". Apaixonado pela cidade do Natal pesquisou, escreveu e publicou Geografia do Brasil holandês, pela editora José Olympio em 1956. Por meio das memórias locais, "Câmara Cascudo busca desvendar esses mistérios do tempo dos flamengos. Contudo, procura entendê-los na forma de sua circunstância viva na memória." (PUNTONI. 2012. p. 32). Assim, pode-se afirmar que "o período de domínio flamengo era, antes, 'uma fase quase doméstica nas lembranças coletivas. Uma espécie de hégira, dividindo um tempo distante e nevoento" (CASCUDO. 1956. p. 13 apud PUNTONI.2012.p. 32), a qual persistia na memória ${ }^{1}$ coletiva da sociedade.

Assim, quando nos deparamos com uma imagem de campo sem fim; com várzeas a perder de vista, onde o céu encontra-se com a terra; quando olhamos para uma paisagem abrasiva que a imagem nos faz cair num silêncio profundo onde somos persuadidos pela imaginação a ouvir o canto da cigarra.

Esta imagem verde e úmida do litoral é o principal mecanismo da memória que nos carrega subitamente para o mundo colonial no século XVII, quando o holandês viveu no norte da colônia americana.

Câmara Cascudo tinha razão ao afirmar que este tema era íntimo nas vivências e memórias dos moradores da atual região nordestina do Brasil. O Brasil holandês vive por meio das várias imagens pintadas pelos pintores de João Maurício de Nassau, Frans Post e Albert Eckhout.

Na tela $O$ carro de bois, a paisagem mostra-nos uma terra de colinas verdejantes e água abundante. A natureza é representada no quadro pela grande árvore de acácia à esquerda, como também podemos ver, claramente, no quadro, os temas antrópicos nas figuras masculinas. Estes são os escravos na lida diária do trabalho. O carro de tração animal é puxado por dois bois, essa era a melhor máquina de deslocamento para vencer as grandes distâncias percorridas pelos colonos nessas terras sem fim.

Este quadro, um dos primeiros a serem pintados em Pernambuco, mostra provavelmente a vila Formosa de Serinhaém, importante região produtora de açúcar. Numa visão idílica dos homens no trabalho, Post não hesita em mostrar 
escravos mais descontraídos e relaxados que segundo Pedro e Bia Corrêa do Lago, os negros aparecem como "quase livres e independentes" (2006. p. 92).

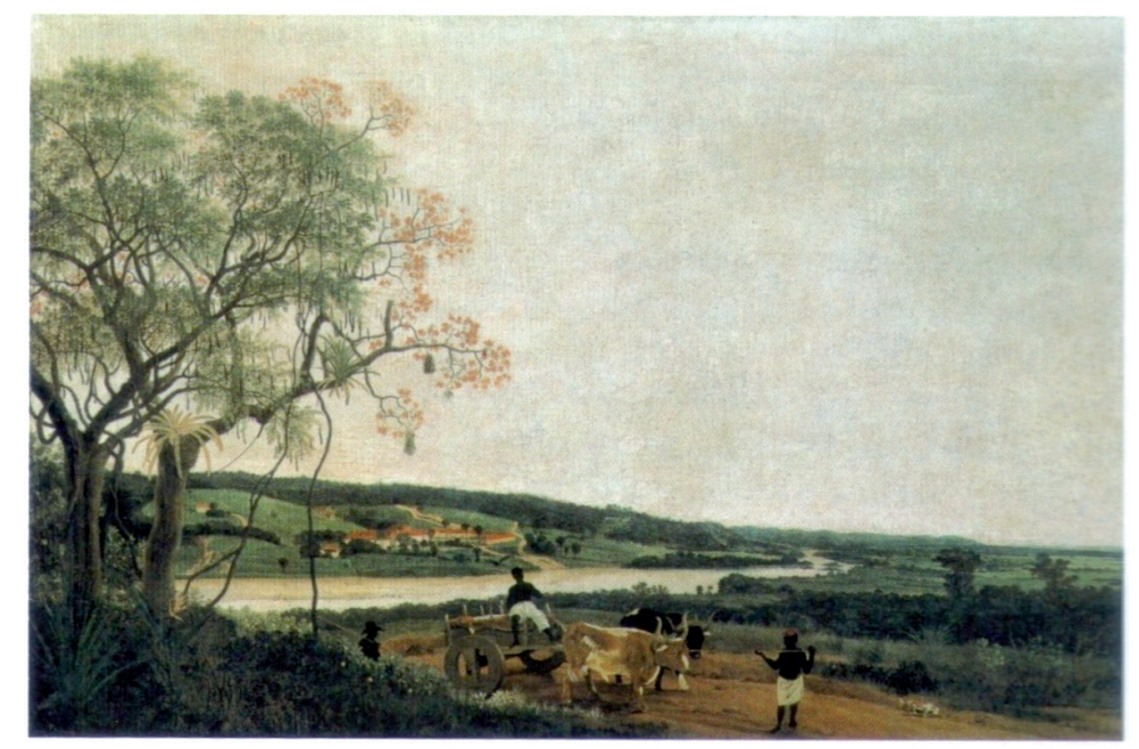

Figura 1: Frans Post. O carro de bois, 1638. Óleo sobre tela. 62 ×95 cm, Museu do Louvre, Paris.

O quadro tem elementos naturais e humanos, podendo ser classificado como rural, pois, segundo Van den Boogaart (2005), "tentou reproduzir o complexo da lavoura por inteiro", agregando à paisagem principalmente os conceitos constitutivos do mundo ruralizado que o colonizador holandês vai encontrar na América.

Das décadas de 1940 e 1950, quando foram lançados estudos mais apurados sobre o tema da dominação holandesa no Brasil, vale lembrar o Tempo dos flamengos, de José A. G. de Mello, e o estudo de Câmara Cascudo, já mencionado aqui, aos dias atuais. "A memória funciona como um fio condutor, como um mecanismo para entender o passado." (OLIVEIRA. 2012. p. 69) e o "Brasil holandês" é um assunto recorrente nos vários estudos propostos sazonalmente ${ }^{2}$.

Frans Post foi o grande responsável por apresentar ao olhar holandês as paisagens americanas. Ele mesmo, um colonizador, capturou os elementos constitutivos da colônia por meio da sua visão de mundo e representou esta paisagem a seus contemporâneos. Entendemos desse modo, que as imagens que serão analisadas neste estudo são portadoras de discursos criados por Frans Post, que "produziu um conceito de paisagem 'brasileira' [ou americana] para o período colonial, demonstrando as cores e a riqueza de detalhes da vida social 'brasileira' [ou nativa] pelos olhos do colonizador". (VIEIRA. 2012. p. 15). 
O conceito de paisagem criada por Frans Post, somada às imagens de Albert Eckhout, formam um grande arquivo visual do período de dominação batava na América. Quando juntas, essas imagens constituem-se poderosas ferramentas de memória povoando o imaginário das pessoas de ambos os lados do Atlântico.

O ano é 2012. Em exposição intitulada "Trajetória Paulo von Poser", comemorativa dos 30 anos de exposição do artista de Santos, em cartaz no Museu Brasileiro da Escultura (MuBE) na cidade de São Paulo, quatro imagens em tamanho semelhantes às pinturas de Albert Eckhout chamam a atenção do pesquisador.

Eram quatro figuras "etnográficas" das oito pintadas por Albert Eckhout durante sua estadia na colônia, para o príncipe de Nassau, governador da colônia holandesa no século XVII. As telas dispostas na altura do olhar ${ }^{3}$ fazem o observador erguer a cabeça a fim de admirar a releitura contemporânea. Perfazem a mostra as telas Mestiço, Negra, Negro e Mameluca ${ }^{4}$.

No século XVII a América era um espaço privilegiado para representar tipos humanos diversos ao europeu. Tanta diversidade de gente enriqueceu se assim podemos dizer os pincéis de Eckhout, homens e mulheres negros, marrons, amarelos, fosse pela miscigenação ${ }^{5}$ ou do bronzear da luz solar, faziam a pluralidade de tons da pele das pessoas. Era um "paraíso" de "cores antropológicas".

Dentro do sistema social holandês, que reconhecia essa diversidade de tipos humanos na América, Eckhout realizou o seu trabalho pintando seus retratos etnográficos. Vale lembrar a opinião da historiadora Rebecca P. Brienen: "No século $\mathrm{XVII}$,contudo, os principais grupos éticos não europeus reconhecidos pelos holandeses no Brasil limitavam-se a Brasilianen, Tapuya, africanos, mulatos e mamelucos; e não é uma coincidência que esses sejam justamente aqueles representados na série de retratos etnográficos de Eckhout." (BREINEN. 2010. p. 95).

As releituras de Paulo von Poser, que ora utilizamos como fonte imagética secundária, representam, na sua maioria, um espaço árido, uma vez que o artista se preocupa demasiadamente em pintar as pessoas que Albert Eckhout representou no passado (século XVII). As imagens de Poser convertem-se num trabalho rápido, feito em outra época, que utiliza materiais diferentes ${ }^{6}$ aos que Eckhout usou, não traz o cuidado excessivo com a paisagem do horizonte que Eckhout fez nas suas imagens. Mesmo assim, é um trabalho digno de estudo, capaz de trazer à tona as lembranças de pessoas que viveram em outros tempos.

Os retratos que Albert Eckhout realizou na colônia são para Rebecca P. Brienen, "extraordinários, sem precedentes na história da arte" (BRIENEN. 2010. p. 95). Para mim, não são apenas retratos - classificá-los assim seria simplista demais. Essas imagens são pinturas que trazem pessoas num espaço tropical exótico, mítico e estranho ao olho do holandês seiscentista. É um espaço rico em detalhes, com vegetação delgada e vertical extremamente simétrica aos corpos humanos 
ali pintados. Podemos ver a cana-de-açúcar, o mamoeiro, dois tipos de palmeiras tropicais e o cajueiro com seus frutos dependurados sobre a cabeça da mulher mameluca. Se pudermos classificar uma das telas de Eckhout como a mais rica em vida natural que mencionamos aqui, essa seria Mameluca de 1643.

Uma mulher de vestes brancas equilibra na mão direita um cesto de palha ricamente disposto com flores nativas. Existem pelo menos sete espécimes de flores na tela, na cabeça um arranjo de flores brancas adorna a mulher. Pela pose da mesma, quase poderíamos dizer que é de origem fidalga uma mulher europeizada. Segundo a historiadora Izabel M. dos Santos:

Ela [mameluca] transpira sensualidade através do seu decote, postura e até mesmo no simples

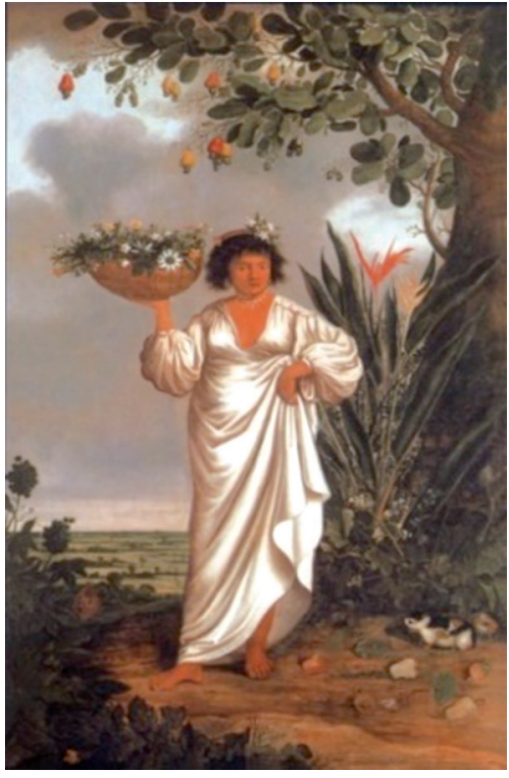

Figura 2: Albert Eckhout. Mameluca

(Mameluc Woman), 1643. $267 \times 160 \mathrm{~cm}$,

Nationalmuseet, Copenhague. gesto de levantar o vestido mostrando assim parte de sua perna. Ela usa brincos, colares pulseiras, e seus modos são bastantes europeizados. Ela está descalça, assim como o "Homem mulato" [de 1643] e isso atesta que embora ela já tenha hábitos e modos europeus, ela ainda se encontra num patamar inferior ao do europeu. (SANTOS. 2008. pp. 4-5)

Se não fosse pelos pés descalços que denunciam sua posição social, a mulher mameluca poderia estar inserida nos ciclos sociais da "civilização europeia".

O chão repleto de cajus indica que a estação é o verão, época de fartura do fruto. Dois porquinhos da índia - ou preá do reino - enriquecem ainda mais o colorido do quadro ${ }^{7}$. A mulher está num jardim, teria Albert Eckhout buscado inspiração na tela A primavera de Sandro Botticelli ${ }^{8}$ ? Assim como a alegoria da primavera que Botticelli pinta no seu quadro, a mulher mameluca de Eckhout é parte da natureza, um elemento do paraíso selvagem que era a colônia para os neerlandeses.

Talvez resida aí a grande semelhança entre os trabalhos de Frans Post e Albert Eckhout, ambos engajados num ambicioso projeto político planejado pelo príncipe de Nassau. Os dois artistas pintaram o humano em meio à mata nativa; para eles o homem é parte integrante do meio, o espaço é modificado por este que age dando uma nova paisagem à América. 
Estes mesmos personagens também foram representados em desenhos por Zacharias Wagener no seu Thierbuch. Este cronista somava a comitiva administrativa de Maurício de Nassau.

A partir desta experiência de encontrar e ver imagens tão caras, e, naquele momento, próximas de mim, pude constatar o interesse coletivo por imagens tão antigas que fazem um modo de ver e sentir o passado e a cultura visual no Brasil. Esta, em última análise, inserida numa cultura ocidental em formação muito mais ampla em trocas atlânticas entre América colonial e a República dos Países Baixos. Ou seja, existe em comum um "passado compartilhado entre Brasil e Holanda durante o século XVII" (BOOGAART. 2012.p. 47).

As imagens ali expostas são as referências culturais do artista, mostrando como von Poser recorreu ao passado para fazer uma releitura "do que foi" com imagens que povoam o imaginário do europeu, do pernambucano, do paulista de Santos e de muitos brasileiros. De certa forma, a história da Nova Holanda ainda pode ser vista, pode ser contada de outras formas, estando disponível para as novas gerações tirarem suas conclusões "do que foi" de maneira a dar um novo sopro à história.

Sob este prisma, as imagens do Brasil holandês é uma forma de memória. Interesse comum de pesquisadores, tanto as imagens de Frans Post quanto às de Albert Eckhout representam um espaço social e cultural plural desde sua gênese. Para Gilberto Freyre, “(...) a lenda persistia. Para ele, o tempo dos flamengos continua igual na imaginação de nosso povo ao tempo dos mouros na imaginação dos portugueses." (PUNTONI. 2012. p. 31).

Como tornar essa visão para o passado uma questão historiográfica? O olhar historiográfico do professor Rômulo Luiz Xavier do Nascimento sobre a ocupação holandesa do século XVII, na América, convence-nos que muito ainda pode ser estudado e interpretado:

\footnotetext{
Aqui, se as marcas da ocupação holandesa não são visíveis a olhos atuais, o próprio fato de, mais de três séculos depois de sua expulsão, tocarmos no assunto, já prova por si só a importância historiográfica do tema. $\mathrm{O}$ assunto ainda hoje se sustenta com largueza na variada produção de crônicas, livros e teses sobre a presença batava. (NASCIMENTO. 2007. p. 132).
}

Podemos acrescentar à lista acima as imagens do Brasil holandês, a larga produção iconográfica sobre a colônia promovida por Nassau e que constituiu, para os europeus, uma nova forma de ver o mundo além do Atlântico. Novas possibilidades abriram-se para o conhecimento do homem europeu pelas imagens, de maneira que pôde "conhecer" melhor outra terra e o seu outro. Hoje, a maior herança da ocupação holandesa para o Brasil são essas imagens como resquícios 
de sua breve passagem. Dentre elas, as paisagens de Frans Post possuem um valor fundamental que está no cerne deste estudo.

Nossa proposta é estudar as imagens do mundo colonial que o homem holandês formou na América, durante sua estadia de 24 anos, com principal destaque para os sete anos de governo do príncipe João Maurício de Nassau, pois ele trouxe consigo nomes da arte dos Países Baixos, entre eles Frans Post, que se tornaria o pintor das paisagens coloniais.

A partir de algumas paisagens de Frans Post, indago sobre o modo como o holandês via o espaço colonial durante o período seiscentista, pois no momento da chegada do pintor, essas terras faziam parte dos domínios coloniais batavos.

É fundamental ter em mente a participação da obra pictórica de Frans Post como parte de um projeto político neerlandês, no qual descrever os espaços por meio de imagens fazia parte de práticas integradas à própria estabilização da presença colonial no continente americano.

O pintor holandês Frans Janszoon Post (1612 - 1680), nascido e formado na cidade de Haarlem, na Holanda, veio para os trópicos em 1637, com apenas 24 anos, e regressou com Nassau à Holanda em 1644, permanecendo em terras coloniais por 7 anos. Foi um dos integrantes da comitiva científica e artística do administrador da colônia holandesa na América, o conde Johan Maurits Van Nassau-Siegen. Esta incursão fora patrocinada pela Companhia das Índias Ocidentais ${ }^{10}$ (WIC - WestIndische Compagnie), que era detentora da concessão de posse das terras no norte da América portuguesa.

Muito já se sabe da história dos grandes feitos de Pernambuco. Capitania de prestígio no Reino, lugar de riquezas que despertou a cobiça das nações estrangeiras e rivais de Portugal. Este espaço era (grande) produtor de açúcar e ponto estratégico para administrar boa parte do território da colônia. Um espaço que era um conjunto de terra na sua forma mais simples, e, também, espaço cultural modelado pelo homem em sociedade. $\mathrm{O}$ espaço tem forma, tem cor, tem volume, é um cenário onde o homem é parte constituinte do meio e espectador ao mesmo tempo. O espaço é uma construção simbólica cultural única; cabe um nome próprio: Paris, Natal, Haarlem, Recife ou ainda o Atlântico (DARDEL. 2006).

Entre os vários historiadores que se preocuparam em estudaressa espacialidade, cumpre citar Evaldo Cabral de Mello, que em sua vasta obra contempla: Olinda restaurada (2007), na qual faz uma análise da guerra empreendida por Portugal para reconquistar os territórios coloniais perdidos para os holandeses; O Negócio do Brasil (2011), no qual busca entender os trâmites diplomáticos que envolveram as nações modernas - Portugal e Holanda - na grande negociação que entregaria o norte do Brasil novamente ao domínio dos portugueses; Rubro veio (2008), que empreende uma análise sobre o sentimento nativo que é próprio do pernambucano 
em suas relações com o Brasil. Recentemente os dois últimos lançamentos: o Brasil holandês (2010), que contempla a administração nassoviana na Nova Holanda, e O Bagaço da Cana (2012) que faz uma análise de documentos domésticos dos engenhos relativos à produção de mercadorias (açúcar) das capitanias de Pernambuco, Paraíba e Rio Grande (do Norte) dentre outras capitanias coloniais.

Outro grande nome da historiografia que trabalhou com essa época ${ }^{11}$ foi o historiador José Antônio Gonçalves de Mello, em Tempo dos Flamengos (1987). Segundo o autor, durante os anos de ocupação neerlandesa no norte da colônia a cultura holandesa teria permeado a vivência e a cultura do Brasil.

Outro grande intérprete da nossa historiografia foi o sociólogo e historiador Gilberto Freyre, que nunca realizou um grande trabalho sobre o Brasil holandês ${ }^{12}$. Gilberto Freyre, no seu clássico ensaio sobre a família patriarcal do Brasil, ainda no ano de 1933, ressaltara o trabalho das imagens para a pesquisa histórica: "quanto à iconografia da escravidão e da vida patriarcal está magistralmente feita por artistas da ordem de Frans Post, Zacarias Wagner, Debret e Rugendas" (FREYRE. 2006. p. 50).

Recentemente, a tese de Daniel de Souza Leão Vieira Topografias Imaginárias: a paisagem política do Brasil holandês em Frans Post (2010), analisa e aprofunda o debate sobre as imagens de Frans Post, compreendendo-as como paisagens formadoras de um pensamento político da época. Partindo dos conceitos da geografia cultural, história cultural e imagem, Vieira faz uma análise das paisagens de Frans Post, tanto pela pesquisa iconográfica como também teorizando a paisagem colonial do Brasil holandês.

Recorremos a estes autores para salientar a inserção da nossa pesquisa, uma vez que temos como objeto de estudo fontes iconográficas contemporâneas à época que eles escolheram para estudar.

Pernambuco é um espaço ao qual a historiografia dedicou grandes interpretações, não apenas quando o assunto versa sobre a Invasão Holandesa, mas sobre várias temáticas que se dedicaram a fazer da interpretação da história de Pernambuco a própria História do Brasil.

No século XVII, os holandeses, segundo Mello, “após tentativas frustradas de ocupar a sede da administração portuguesa, na Bahia, preferiram ir direto à fonte da riqueza brasileira: a Capitania de Pernambuco e seus açúcares" (MELLO In OLIVEIRA. 2005. p. 1). Da presença dos holandeses na América portuguesa surgiram as primeiras representações visuais da nova terra nos gêneros da pintura clássica, em especial a paisagem, retratada pela primeira vez pelos olhos e pincéis de Frans Post. Assim sendo, Carla Mary conta-nos que "o novo mundo será visto, pesquisado e retratado com rigor, tanto do ponto de vista artístico quanto científico, e tudo será mérito de [Maurício de Nassau] um nobre alemão de família neerlandesa." (OLIVEIRA. 2006. p. 117). 
O espaço colonial será amplamente documentado pelos holandeses tanto por imagens como também pelos textos científicos que serão nossas fontes históricas de pesquisa.

\subsection{Paisagem, espaço e história}

A relação entre paisagem e espaço é a primeira questão que precisamos enfrentar:

... a paisagem adquire o aspecto visível do espaço. Ela é a epiderme do corpo do mundo (se me arvoro a usar tais metáforas). Visibilidade do território, exterioridade do relevo, manifestação do espaço, essa superficialidade topográfica pode levar à idéia de que a paisagem é um véu que deve ser removido para que se chegue ao verdadeiro objeto de estudo, o espaço. Esse pensamento se funda na tradição que toma a imagem como cópia do real, e, portanto efêmera, perecível e não confiável.

Contudo, espaço é tanto uma realidade exterior quanto uma representação. E por representação não concebo um falseamento do real, tal como alguns autores quando falam em ideologia. A representação é a construção de uma visão de mundo. (VIEIRA. 2006. pp. 04-05).

John B. Jackson, um dos principais autores que se debruçaram sobre este tema, afirma que "a paisagem não é espaço" (2006. p. 04), mas sim, “... a paisagem é um conjunto de espaços, espaços esses transformados pelas relações humanas." (2006. p. 04). A paisagem se depara com o espaço a partir de toda dispersão dos objetos e sua organização (condensação) pela cultura neste mesmo espaço. Assim, podemos entender que a paisagem seria a parte visual, uma construção imaginária da visão e do pensamento do espaço praticado ou por ser praticado, é a imagem do espaço, é uma representação, se preferirmos, pois pode ser plasmada em cores numa tela, pode ser fotografada por lentes e, nisso, o espaço por meio da paisagem se faz presente para percepção do homem.

Frans Post retratou as paisagens brasileiras e foi um expoente artístico da vida pictórica nas Américas,

sua obra está intrinsecamente ligada ao cenário histórico em que viveu e às características da arte neerlandesa do século XVII, onde a pintura de paisagem era um gênero comum e de mercado garantido, daí a repetição constante de algumas paisagens, como as ruínas de Olinda, em sua obra. (OLIVEIRA. 2006. p. 123). 
Este artista nascido e formado na escola de Haarlem era um representante desta escola holandesa:

\begin{abstract}
... na vasta produção da pintura holandesa do século XVII, um dos temas predominantes é a paisagem, e alguns dos maiores talentos do período expressaram-se nesse ramo da pintura (...), representavam-se vistas panorâmicas, florestas, dunas e estradas rurais, rios e canais" e "as obras de Frans Post têm um interesse histórico especial. De 1637 a 1644 ele fez vistas do Brasil. (SLIVE. 1998. pp. 177 \& 192).
\end{abstract}

Slive mostra a importância dada, na época, a esse tipo de pintura nos Países Baixos e pelo próprio Maurício de Nassau ao Brasil, tanto que Frans Post retratou várias paisagens da colônia americana.

Ora, a obra de Frans Post contem informações preciosas da vida cotidiana tais como economia, sociabilidades, miscigenação, relações étnicas entre negros escravos, índios e colonizador português. Acima de tudo, a importância de estudar a obra de Post reside na perspectiva de observar a paisagem criada, uma vez que Post pintava para atender a uma demanda social que queria ver as possessões coloniais no ultramar, pintando paisagens exóticas para dar ao público consumidor o que desejavam ver. Estas são mundos vivos, cheias de representações sociais, de memórias que podem ser reconhecidas naquele espaço pictórico. Segundo Simon Schama, existe uma memória construtora da paisagem, ou seja,

\begin{abstract}
Paisagem é cultura antes de ser natureza; um constructo da imaginação projetado sobre a mata, água, rocha. (...) No entanto, cabe também reconhecer que, quando uma determinada idéia de paisagem, um mito, uma visão, se forma num lugar concreto, ela mistura categorias, torna as metáforas mais reais que seus referentes, torna-se de fato parte do cenário. (SCHAMA. 1996. p. 70).
\end{abstract}

O conceito de paisagem que Schama nos apresenta é uma concepção amadurecida de suas pesquisas sobre a Holanda durante o século XVII na obra $O$ desconforto da riqueza (1992) $)^{13}$, o qual foi desenvolvido plenamente em seu livro Paisagem e memória $(1996)^{14}$.

Logo, a paisagem pode ser construída a partir dos planos pré-estabelecidos, sendo também patriótica, servindo aos interesses do grupo dominador que governa o Estado. A pintura de paisagens alia-se desta forma ao ideal (interesse) do Estado neerlandês de conhecer o espaço para facilitar a conquista, ou seja, coligir informações, obter conhecimento por meio das imagens para dominar. 
Atualmente, na história cultural, a imagem e a paisagem convertem-se em um documento possível de análise dentro de um recorte histórico. Jeremy Black, no seu trabalho Mapas e História (2005), faz um estudo de como certas imagens (mapas) surgem, como elas foram confeccionadas e como foram pensadas dentro de sua época.

Para Black, por exemplo, nos séculos XVI e XVII os mapas e a sua função nos livros de Atlas eram assim entendidos:

As imagens visuais que os Atlas históricos proporcionam influenciaram na criação e sustentação de noções de situação históricas e são particularmente apropriadas como tema de investigação devido à recente ênfase em nações como comunidades políticas imaginadas, ênfase no papel de imagens como meio de criar percepções de poder e, de modo mais geral, ênfase em aspectos iconográficos da autoridade política e cultural. (BLACK. 2005. p. 11).

Seguindo esta linha de pensamento, é interessante citar Durval Muniz de Albuquerque Jr.

(...) a paisagem não é pura natureza, não é repouso para os sentidos. A paisagem é obra da percepção humana, da relação de seus sentidos com o meio que o cerca, a paisagem é obra da mente, é um conceito através do qual o homem dá sentido de conjunto a toda dispersão, ao caos dos elementos naturais que estão à sua volta. (ALBUQUERQUE JR. 2008. p. 204).

Assim como os mapas, as pinturas de paisagens serviam aos interesses do Estado, informavam sobre relevos, rios, cidades, topografias, etc.

Estas representações foram usadas nas estratégias de guerra. Serviam para organizar o espaço com sua latitude, longitude dentro de uma perspectiva imaginada e trabalhada pela arte. Eram objetos econômicos e tinham função prática na sociedade holandesa, e, enfim, tinham finalidade decorativa dentro dos espaços domésticos e nas repartições públicas do Estado Nacional holandês e em outros países da Europa:

A noção de visão também se alterou. Os avanços científicos empreendidos pelos holandeses no século 17, especialmente na ótica, fizeram-nos enfatizar a visão como o sentido através do qual Deus revela sua criação mais claramente para a humanidade. Essa admiração pelo sentido da visão levou os pintores a tentar "descrever" (mimetismo) o mundo como eles o viam. A cartografia holandesa tem sido ligada à pintura holandesa na medida em que ambos 
tentavam a "descrição" da realidade física. Dessa forma, passou-se a dar maior valor ao "realismo" geográfico na cartografia do que aos mapas estilizados mais antigos que não dependiam de uma descrição topográfica precisa. Vermeer apresentou Clio com um mapa histórico das Províncias Unidas da parede. (BLACK. 2005. p. 28).

O pensamento de Black aproxima-se muito das análises de Svetlana Alpers (1999), quando esta afirma ver grande intimidade entre os mapas geográficos e a arte holandesa da época de ouro, de maneira que não existiu um limite concreto entre as representações gráficas (mapas, por exemplo) do espaço e as paisagens do Brasil holandês, ambos sendo práticas que se comunicam num mundo cultural onde a imagem descreve os espaços. Segundo Alpers "o objetivo dos pintores holandeses era captar, sobre uma superfície, uma grande quantidade de conhecimentos e informações sobre o mundo." (ALPERS. 1999. p. 247).

Aqui é importante observar a grande diferença entre as pinturas italianas e as pinturas holandesas nessa construção do espaço na arte da pintura entre os séculos XVI e XVII, entre a forma de percepção do mundo e do espaço entre os holandeses e os italianos. Segundo Alpers,

\footnotetext{
Em grande parte, o estudo da arte e de sua história tem sido determinante pela arte italiana e por seu estudo. Esta é uma verdade que os historiadores da arte correm o risco de ignorar, em sua atual tendência a diversificar os objetos e a natureza de seus estudos. A arte italiana, e sua evocação retórica, não só definiu a prática da tradição central dos artistas ocidentais como também determinou o estudo de suas obras. Quando me refiro à concepção de arte na Renascença italiana, tenho em mente a definição albertiana do quadro: uma superfície ou painel emoldurado a certa distância do observador, que olha através dele para um segundo mundo ou um mundo substituto. Na Renascença, esse mundo era um palco no qual as figuras humanas praticavam ações significativas baseadas nos textos dos poetas. Trata-se de uma arte narrativa. E a ubíqua doutrina $u t$ pictura poesis era invocada para explicar e legitimar as imagens através de sua relação com textos prévios e consagrados. (ALPERS. 1999. p. 27).
}

Existe uma forte tradição no mundo Ocidental após o Renascimento na padronização da arte a partir das referências italianas. A maior parte das pessoas sente e vê a arte partindo do modo italiano de perceber o mundo, no qual as figuras humanas representam os textos clássicos nos espaços pintados pelos artistas italianos. Em parte, essa é uma tradição "comprada" pelos artistas e acadêmicos do século XIX e como tal, legando ao Ocidente uma forma de pensar a arte ${ }^{15}$. 
Fazendo contraponto a esse padrão estabelecido, ou mesmo se podemos chamar de uma "ditadura" da arte italiana, existem as imagens holandesas confeccionadas durante o século XVII que trazem outro modo de ver a arte partindo das descrições do mundo.

Quando os - vários - talentos holandeses na arte de pintar se deram conta que o mundo estava disposto para a visão e que esse sentido pode ajudar a representar o mundo visível, o sucesso foi estrondoso, uma vez que não era preciso apenas fazer telas com temas grandiosos ao gosto das províncias do sul. Podiam-se representar pessoas em retratos, fazer cenas internas ao estilo de Jan Vermeer. Pintar paisagens com descrição espacial muito próxima do real torna-se comum na Holanda seiscentista. Frans Post não foge à regra, uma vez que foi fiel ao conceito de descrição, que é a representação espacial e alegórica da natureza e dos elementos constituintes do espaço. Ele emprega também na pintura o conceito de mimetismo. O conceito de descrição irá perpassar todo o estudo da arte holandesa, afirma Svetlana Alpers.

Quando olhamos uma paisagem, nós, agentes culturais, procuramos ver e conhecer o espaço, segundo Ortelius: “... o homem nasceu para contemplar o mundo". (BESSE. 2006. p. 28). O presente trabalho pretende problematizar a construção do olhar europeu na paisagem, pois ela reúne em si todos os elementos geográficos como a água, a terra, a pedra, o céu, os vegetais e tem na sua "epiderme" os elementos constitutivos da sociedade, pois constam igrejas, casas, homens e mulheres vestidos ou sem roupas, é a relação mais íntima do humano com a terra ${ }^{16}$.

A paisagem é uma vista, é uma forma de ver o mundo, é "essencialmente mais mundo do que natureza, ela é o mundo humano, a cultura como encontro da liberdade humana com o lugar do seu desenvolvimento; a Terra." (BESSE. 2006. p. 92). Ainda segundo Besse,

[paisagem é...] um olhar vivo, em outras palavras, um ímpeto, uma intencionalidade presente e que atravessa o espaço que se abre entre o aqui e o distante. Em suma, não há paisagem sem profundidade, uma profundidade que se dá a ver sob a forma de uma presença nos longes, de um ser na distância que significa o espoco da vida. A profundidade da paisagem é a da existência. (BESSE. 2006. p. 92).

A paisagem é um espaço, um lugar complexo com sentidos e vivências sociais concedidos por homens. Vamos analisar a paisagem por meio da numerosa obra artística do neerlandês Frans Post ${ }^{17}$. Acreditamos ainda que sua pintura permite que a História tome como objeto de estudo as formas de produção de sentido, ou seja, a representação pictórica dando sentido aos processos sociais ${ }^{18}$. 
Os últimos anos têm demonstrado a preocupação por parte de pesquisadores e historiadores, tanto da arte quanto da historiografia tradicional, em proceder a uma revisão nos trabalhos e estudos de imagens. Os novos trabalhos trazem à luz novos temas e interpretações sobre a importância e utilização das imagens ${ }^{19}$ na pesquisa histórica com enfoque também na história do Brasil. A proposta desenvolvida aqui pretende analisar a paisagem criada por Frans Post e a vida tomada por esta mesma paisagem. Quando afirmamos que a paisagem toma vida própria queremos dizer que, para o período de dominação holandesa, recorreremos às paisagens de Frans Post como forma da realidade. Mas advertimos que estas imagens são apenas uma (parte da) visão, um modelo criado a serviço dos interesses de uma administração colonial por meio da metrópole, pois Maurício de Nassau estava intrinsecamente ligado aos desejos metropolitanos. Como príncipe e herdeiro da nobreza europeia, Nassau deveria atender aos requisitos e predeterminações das elites esclarecidas dos Países Baixos setentrionais.

\section{CONSIDERAÇÕES FINAIS}

A pretensão deste trabalho foi discutir os conceitos de memória e de paisagem tomando como fonte duas imagens uma paisagem de Frans Post e uma figura etnográfica de Albert Eckhout. Utilizamos, para este fim, uma metodologia que privilegiou, desde o início, a imagem como fonte de documento para o conhecimento histórico.

Acreditamos que estas imagens carregam em seus espaços plásticos, ou seja, em suas tintas, representações do mundo natural e antrópico/social que o holandês viu na América e que perseguimos nas fontes pictóricas por meio da memória.

Post e Eckhout descreveram a terra e narraram os fatos sociais. O que era diferente aos olhos tinha espaço garantido nas descrições e relatos visuais que chegaram à atualidade. Descrição de uma natureza exótica, de centros urbanos, vilas, espaços que abrigavam as ações humanas.

Concluímos que Frans Post foi um pintor que se interessou muito em mostrar a vida rural. Pintou o campo, a várzea, os rios e o engenho. Representou o negro escravo na lida do trabalho compulsório e em momentos aprazíveis de danças, pintou o colonizador na movimentação dos negócios rurais, interessou-se em mostrar para seus conterrâneos o modo de viver de alguns homens simples que encontrara na América.

Eckhout fez o retrato mais fiel do nativo, representou o índio, o negro escravo e como Post pintou a paisagem da fazenda, do latifúndio, deu a metrópole o que ela desejava como diria a historiadora Rebecca Parker Brienen, um cheio de cores e formas. 
Evidentemente, esses quadros são também um mundo visual subjetivo, onde a paisagem deixa fluir a imaginação sobre o espaço, essa subjetividade pode ser percebida em todo o trabalho de ambos os artistas. As imagens constroem um tempo onde o holandês, por meio do seu engenho intelectual e força militar, conquistou a região norte da América portuguesa e impôs seus desejos e técnicas na constituição espacial da terra.

A iconografia apresentada por Post e Eckhout nos oferece a oportunidade de conhecermos um mundo, uma época, a história de 24 anos de dominação e de governo por parte desses europeus setentrionais. Por meio de seus olhos e pincéis podemos ver a paisagem da América holandesa.

\section{CITAÇÕES E NOTAS DE RODA PÉ}

* $\quad$ Este texto é parte integrante $\left(1^{\circ}\right.$ capítulo) da minha pesquisa de mestrado realizada no PPGH na Universidade Federal do Rio Grande do Norte - UFRN sob orientação do Prof. Dr. Francisco das Chagas F. Santiago Junior.

1 Segundo o historiador francês Jacques Le Goff memória é: “A memória, como propriedade de conservar certas informações, remete-nos em primeiro lugar a um conjunto de funções psíquicas, graças às quais o homem pode atualizar impressões ou informações passadas, ou que ele representa como passadas.” (LE GOFF. 1996. p. 423).

BRIENEN, Rebecca Parker. Albert Eckhout: visões do paraíso selvagem: obra completa; trad. de Julio Bandeira. Rio de Janeiro: Capivara, 2010. BOOGAART, Ernst van den. As perspectivas da Holanda e do Brasil do "Tempo dos flamengos". In: Brasil Holandês: história, memória e patrimônio compartilhado. VIEIRA, Hugo C.; GALVÃO, Nara N. Pires. \& SILVA, Leonardo Dantas. (Orgs.). São Paulo: Alameda, 2012. DUPARC. Frederik J. Frans Post na pintura holandesa do século XVII. In: LAGO, Pedro e Bia Corrêa do. Frans Post (1612-1680): obra completa. Rio de Janeiro: Capivara, 2006. LAGO, Pedro \& Bia Corrêa do, Frans Post (1612-1680): Obra Completa. Rio de Janeiro: Capivara, 2006. MENEZES, Catarina Agudo. \& SILVA, Maria Angélica da. Fragmentos visuais da História: O uso das vistas de Frans Post nos estudos de História urbana In: II Encontro Nacional de Estudos da Imagem. Anais, Londrina-PR. Maio de 2009. NASCIMENTO, Rômulo Luiz Xavier do. O desconforto da governabilidade: aspectos da administração no Brasil holandês (16301644). Tese de Doutorado em História na UFF. Niterói. 2008. PUNTONI, Pedro. No tempo dos flamengos: memória e imaginação. In: Brasil Holandês: história, memória e patrimônio compartilhado. VIEIRA, Hugo C.; GALVÃO, Nara N. Pires. \& SILVA, Leonardo Dantas. (Orgs.). São Paulo: Alameda, 2012. 
3 Padronizada no estilo Renascentista albertiana, o modo de ver imagens (sua disposição) em galerias e museus segue um padrão estabelecido pela cultura italiana. Mais detalhes Cf. ALPERS (1999).

4 Os nomes das telas empregados aqui foram consultados no catálogo da exposição Albert Eckhout volta ao Brasil 1644-2002 - Recife, Brasília e São Paulo. 2002/2003.

5 Segundo a historiadora Rebecca Parker Brienen "Uma situação particularmente complicada se desenrolou nas Américas, onde colonizadores, africanos e índios mantiveram atividades sexuais inter-raciais.” (BRIENEN. 2010. p. 95).

6 Identificamos como sendo um trabalho rápido, pois Poser trabalha com giz de cera (desenho) sobre uma tela de linho.

7 "No canto direito da imagem, encontramos um porquinho da índia [se olharmos com mais atenção poderemos ver que são dois, ou seja, um casal desses bichinhos tão peculiares] aos pés da mameluca representada, simbolizando a fertilidade, assim como, os cajus que caem da folhagem acima de sua cabeça." (SANTOS. 2008. p. 5).

8 Segundo Barbara Deimling: "A primavera" de 1482, "A composição representa o império de Vênus, no qual penetram o Amor e a Primavera com a sua abundância de flores. $\mathrm{O}$ quadro foi certamente executado para Lorenzo di Pierfrancesco de Médicis, por ocasião do seu casamento, em 1482.” (DEIMLING. 2005. p. 40). Nesta tela podemos identificar uma imensidão de flores e vegetais, "perto de quinhentas espécies de plantas, das quais cento e noventa são flores, foram identificadas neste quadro.” (DEIMLING. 2005. p. 39).

9 “Esse rótulo é uma descrição diplomática. Afinal, aquele 'passado compartilhado' consistia de uma década de conflito violento, um período muito curto de ocupação holandesa e outra década de guerra destrutiva. Os protagonistas desse conflito lutaram pelo domínio exclusivo de um país. Não estavam inclinados a compartilhar muita coisa ou, caso necessitassem, o fariam estritamente nos seus próprios termos. No entanto, é certamente verdadeiro que os historiadores brasileiros e holandeses compartilharam esse passado por muito tempo. Por mais de cento e cinquenta anos estudaram e escreveram a respeito dele." (BOOGAART. 2012. p. 47).

10 Historicamente, os Países Baixos estavam sedentos por demonstrações de poder (e esse poder encontrava tradução na WIC), tanto economicamente como artisticamente, pois com o emergente capitalismo encontrando terreno fértil em terras holandesas, o século XVII caracteriza-se como o tempo de gloria neerlandês, deixando para trás as cidades italianas 
tanto no aspecto econômico quanto no aspecto artístico. Segundo Freedberg, “... a Holanda superou de muito todas as nações européias - e certamente a Itália - no valor científico e artístico de suas ilustrações da natureza.” (1999. pp. 211-212).

11 Refiro-me a época da invasão holandesa no norte do Brasil.

12 Realizou apenas pequenos ensaios sobre os neerlandeses aqui na América dentre os quais "A Pintura no Nordeste" In: Livro do Nordeste. Comemorativo do primeiro centenário do Diário de Pernambuco. [1925]. Este contribuiu profundamente para o entendimento de vários períodos históricos da região norte e do Brasil.

13 A relação entre os textos de Simon Schama apontada por nós nesta pesquisa ainda encontra forte enlace no texto Dutch Landscapes: Culture as Foreground. In: Sutton, P. C. et al. Masters of 17 century Dutch Landscape Painting. Amsterdam/Philadelphia, 1987. Do mesmo autor publicado no ano de 1987 ainda sem tradução para o português.

14 "Basta pensar numa cultura heterogênea como a holandesa do século XVII para apreendermos que os três regimes (o regime do olhar tradicional Renascentista albertiana que privilegia a arte italiana; o regime do olhar que surge no norte europeu com as pinturas descritivas neerlandesas - ver a introdução de Svetlana Alpers - e o terceiro e último regime do olhar é aquele que joga com o claro/escuro, é o Barroco, "que encontra analogia filosófica no sistema das mônadas de Leibniz.") dos olhares citados conviveram num mesmo meio, e foram escolhidos, de acordo com interesses de cada grupo social específico dentro da sociedade como um todo. Eis o papel de uma história cultural do olhar: desvendar meandros que possam ajudar a entender as dinâmicas sociais, a partir do estudo de certas singularidades." (VIEIRA, 2006. pp. 11-12). Partindo do texto O desconforto da riqueza, de Simon Schama, Vieira classifica o olhar da sociedade holandesa dos seiscentos como sendo plural, se assim podemos dizer.

15 "Foi a base dessa tradição que os pintores do século XIX acharam que deveriam igualar (ou superar). Foi a tradição, ademais, que produziu Vasari, o primeiro historiador da arte e o primeiro autor a formular uma história autônoma para a arte. [...] Desde a institucionalização da história da arte como disciplina acadêmica, as principais estratégias analíticas pelas quais somos ensinados a olhar para as imagens e interpretá-las - o estilo segundo Wölfflin e a iconografia segundo Panofsky - foram desenvolvidas tendo por referência a tradição italiana." (ALPERS. 1999. p. 28).

16 Construção do conceito de paisagem a partir de BESSE (2006). 
17 "Frans Post é considerado o inventor da paisagem no Brasil.” (PESAVENTO. 2004. p. 7). Muitos pesquisadores concordam que Frans Post inventou a paisagem do Brasil. Dado o período histórico, Frans Post pintou a paisagem da colônia holandesa na América, ele executou o primeiro trabalho artístico de representação de uma paisagem colonial.

18 Acreditamos com isso, ser um dos nossos objetivos entender a historicidade criada por Post por meio de suas paisagens. Pois para Gombrich, a arte holandesa tinha aprendido a reproduzir a natureza tão fielmente quanto um espelho. Mas ele adverte! "Arte e natureza nunca são tão frios nem tão polidas quanto um espelho. A natureza refletida na arte reproduz sempre o próprio espírito do artista, suas predileções, seus prazeres e, portanto, seu estado de ânimo." (1999. p. 430).

19 Preocupado em esclarecer sua metodologia de pesquisa ou a forma de pensar a imagem, Jacques Aumont define claramente o seu objeto de estudo. A imagem visual é primordial para o autor (como também para se pensar a paisagem de Frans Post na atual pesquisa), para quem: "A imagem tem inúmeras atualizações potenciais, algumas se dirigem aos sentidos, outras unicamente ao intelecto, como quando se fala do poder que certas palavras têm de 'produzir imagem', por uso metafórico, por exemplo. Convém, portanto dizer em primeiro lugar que, sem ignorar essa multiplicidade de sentidos, aqui só será considerada uma variável de imagens, as que possuem forma visual, ou visível, as imagens visuais." (1993. p.13)

\section{REFERÊNCIAS}

ALBUQUERQUE JR. D. M. (2008). Nos destinos de fronteira: história, Espaços e identidade regional. Brasil: Bagaço.

ALBUQUERQUE JR. D. M. (2009). A Invenção do Nordeste e outras artes. 4. ed. Brasil: Cortez.

ALPERS, S. (1999). A Arte de Descrever: A Arte Holandesa no Século XVII. Brasil: Edusp.

BESSE, J. M. (2006). Ver a terra: Seis ensaios sobre a paisagem e a geografia. Brasil: Perspectiva.

BOOGAART, E. van den. (2012). As perspectivas da Holanda e do Brasil do "Tempo dos flamengos”. In: Brasil Holandês: História, memória e patrimônio compartilhado. VIEIRA, H. C.; GALVÃO, N. N. Pires.; SILVA, L. D. (Orgs.). Brasil: Alameda.

BRIENEN, R. P. (2010). Albert Eckhout: visões do paraíso selvagem. Brasil: Capivara. 
BOXER, C. R. (1961). Os holandeses no Brasil, 1624-1654. Brasil: Companhia Editora Nacional.

CASCUDO, L. C. (1956). Geografia do Brasil holandês. Brasil: José Olympio.

CORBIN, A.(1989). O Território do Vazio. Brasil: Companhia das Letras.

COSGROVE, D. E.; JACKSON, P. (2007). Novos Rumos da Geografia Cultural. In: Introdução à geografia cultural. CORREAA, R. L.; ROSENDAHL, Z. $2^{\text {a }}$ ed. Brasil: Bertrand Brasil.

DEIMLING, B. (2005). Botticelli. Portugal: Paisagem Editora.

DUPARC. F. J. (2006). Frans Post na pintura holandesa do século XVII. In: LAGO, P.; Bia C. Frans Post (1612-1680). Brasil: Capivara.

FREYRE, G. (2004). Nordeste: aspectos da influência da cana sobre a vida e a paisagem do Nordeste do Brasil. 7 ed. Brasil: Global.

FREEDBERG, D. (1999). “Ciência, comércio e arte” In: HERKENHOFF, P. (org.). O Brasil e os Holandeses, 1630-1654. Brasil: Sextante Artes.

GOMBRICH. E. H. (1999). A História da Arte. 16ª Ed. Brasil: LTC.

GREENBLATT, S. (1996). Possessões Maravilhosas. Brasil: EDUSP.

HOLANDA, S. B. (2010). Visão do Paraíso: os motivos edênicos no descobrimento e colonização do Brasil. Brasil: Cia das Letras.

KNAUSS, P. (2006). O desafio de fazer História com imagens: arte e cultura visual. In: ArtCultura, Brasil: v $8, \mathrm{n}^{\circ} 12$.

LAGO, P. \& Bia C. (2006). Frans Post (1612-1680). Brasil: Capivara.

LE GOFF, J. (1996). História e Memória. Brasil: 4. ed. EDUNICAMP.

MACEDO, H. A. M. (2011). História indígena no sertão da capitania do Rio Grande após as Guerras dos Bárbaros. In: ARAÚJO, Marcos A. Alves de, SANTOS, Rosenilson S. (Orgs.). Seridó Potiguar: tempos, espaços, movimentos. Brasil: Ideia.

MELLO, E. C. (2010). O Brasil holandês (1630-1654). Brasil: Penguin Classics. 
MELLO, E. C.(2007). Olinda restaurada: guerra e açúcar no Nordeste, 1630-1654. Brasil: Ed. 34.

MELLO, J. A. G. (2007). Tempo dos Flamengos. Influência da ocupação holandesa no vida e na cultura do norte do Brasil. Brasil: $5^{\circ}$ Edição. TopBooks, Universidade Editora.

NASCIMENTO, R. L. X. (2007). A Flecha e o Mosquete: índios e batavos no Brasil holandês. In: Revista Clio. Brasil: PPGH-UFPE. Edufpe.

OLIVEIRA, F. I. D. (2012). A Iconografia De Frans Post como promotora das identidades locais: Um Olhar sobre "O Forte Ceulen No Rio Grande” In: Revista Inter-Legere. Brasil: UFRN: Núm 10.

PESAVENTO, S. J. (2004). A invenção do Brasil: O nascimento da paisagem brasileira sob o olhar do outro. In: Fênix revista de história e estudos culturais. Brasil: v 1, ano 1, $\mathrm{n}^{\circ} 1$.

PUNTONI, P. (2012). No tempo dos flamengos: memória e imaginação. In: Brasil Holandês: História, memória e patrimônio compartilhado. VIEIRA, H. C.; GALVÃO, N. N. P.; SILVA, L. D. (Orgs.). Brasil: Alameda.

SANTOS, I. M. (2008). Albert Eckhout e a construção do imaginário sobre o Brasil na Europa seiscentista. In: Mneme - Revista de Humanidades. Brasil: v.9. núm 24.

SCHAM, S. (1996). Paisagem e memória. Brasil: Companhia das Letras.

SCHAM, S. (1992). O desconforto da riqueza: a cultura holandesa na época de ouro: uma interpretação. Brasil: Companhia das Letras.

SILVA, F. C. T. (1997). História das paisagens In: Domínios da história: ensaios de Teoria e Metodologia. Cardoso, C. F.; Vainfas, R. (org.). Brasil: Campus.

VIEIRA, D. S. L. (2010). Topografias Imaginárias: a paisagem política do Brasil holandês em Frans Post, 1637-1669. Holanda: Tese de doutorado, Universidade de Leiden.

VIEIRA, D. S. L. (2006). Paisagem e imaginário: contribuições teóricas para uma historia cultural do olhar. In: Fênix. Brasil: vol. 3, ano 3, núm 3.

VIEIRA, H. C. (2012). Brasil Holandês: história, memória e patrimônio compartilhado. In: GALVÃO, N. N. Pires.; SILVA, L. D. (Orgs.). Brasl: Alameda. 
WAGNER, P. L. e MIKESELL, M. W. (2007). Os Temas da Geografia Cultural. In: Introdução à geografia cultural. Brasil: $2^{\mathrm{a}}$ ed. Bertrand Brasil.

WANNER, M. C. de A. (2010). Paisagens sígnicas: uma reflexão sobre as artes visuais contemporâneas. Brasil: EdUFBA.

\section{SOBRE O AUTOR}

Francisco Isaac D. de Oliveira: Historiador pela Universidade Potiguar - UnP/Campus Natal em 2009. Mestre em História e Espaços pela Universidade Federal do Rio Grande do Norte UFRN/Campus Natal em 2013. Professor Tutor do Instituto Federal de Ciência e Tecnologia do Rio Grande do Norte - IFRN/Campus Natal. Professor de História na rede municipal de educação na cidade de São Gonçalo do Amarante província do Rio Grande do Norte - RN/Brasil. E-mail: isaacdantassotemum@hotmail.com 
